\title{
EPISODES FROM THE HISTORY OF
}

THE RARE EARTH ELEMENTS 


\section{Chemists and Chemistry}

\section{VOLUME 15}

A series of books devoted to the examination of the history and development of chemistry from its early emergence as a separate discipline to the present day. The series will describe the personalities, processes, theoretical and technical advances which have shaped our current understanding of chemical science.

The titles published in this series are listed at the end of this volume. 


\section{EPISODES FROM THE HISTORY OF THE RARE EARTH ELEMENTS}

Edited by

\section{H. Evans}

University of Pittsburgh,

Pittsburgh, Pennsylvania, U.S.A.

Kluwer Academic Publishers

Dordrecht / Boston / London 
A C.I.P. Catalogue record for this book is available from the Library of Congress.

ISBN-13:978-94-010-6614-3

e-ISBN-13:978-94-009-0287-9

DOI: $10.1007 / 978-94-009-0287-9$

Published by Kluwer Academic Publishers, P.O. Box 17, 3300 AA Dordrecht, The Netherlands.

Kluwer Academic Publishers incorporates the publishing programmes of

D. Reidel, Martinus Nijhoff, Dr W. Junk and MTP Press.

Sold and distributed in the U.S.A. and Canada by Kluwer Academic Publishers,

101 Philip Drive, Norwell, MA 02061, U.S.A.

In all other countries, sold and distributed

by Kluwer Academic Publishers Group,

P.O. Box 322, 3300 AH Dordrecht, The Netherlands.

Printed on acid-free paper

All Rights Reserved

(C) 1996 Kluwer Academic Publishers

Softcover reprint of the hardcover 1st edition 1996

No part of the material protected by this copyright notice may be reproduced or utilized in any form or by any means, electronic or mechanical, including photocopying, recording or by any information storage and retrieval system, without written permission from the copyright owner. 


\section{TABLE OF CONTENTS}

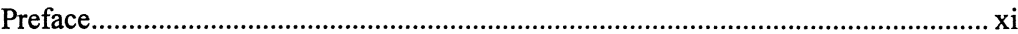

Acknowledgements ............................................................................................. XV

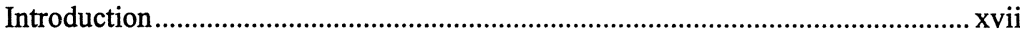

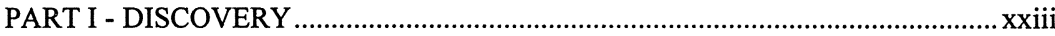

Chapter 1. WHAT DID JOHAN GADOLIN ACTUALLY DO? ............................. 1

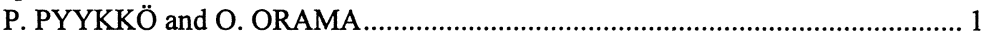

1.1. Johan Gadolin: a short biography and bibliography ................................... 1

1.2. The discovery of the mineral................................................................... 1

1.3. Gadolin's analysis: The 1794 and 1796 papers .......................................... 2

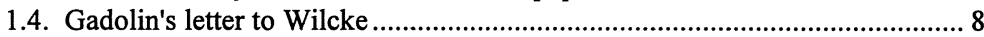

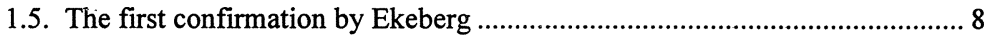

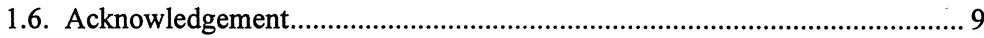

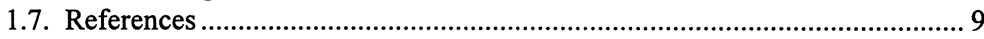

Appendix 1 - Historical nomenclature...................................................... 11

Appendix 2 - The analysis schemes used ..................................................... 12

Chapter 2. THE DISCOVERY OF CERIUM - A FASCINATING STORY ............ 13

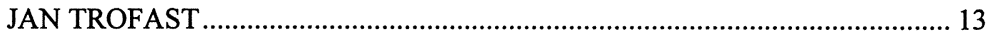

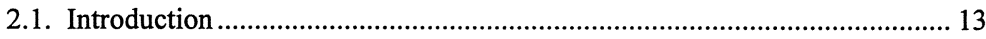

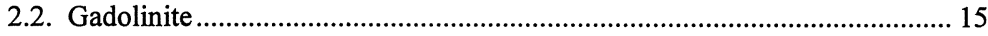

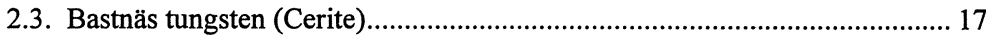

2.3.1. THE QUALITATIVE ANALYSES ................................................ 17

2.3.2 THE QUANTITATIVE ANALYSES .................................................. 28

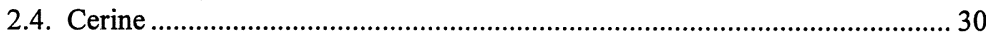

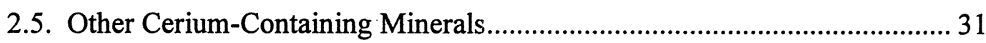

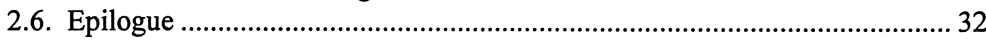

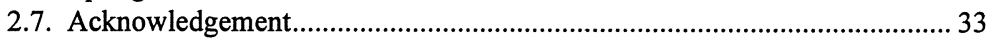

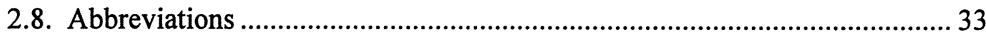

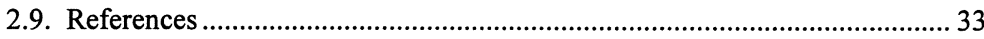

Chapter 3. CARL GUSTAF MOSANDER AND HIS RESEARCH ON RARE

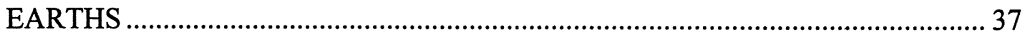

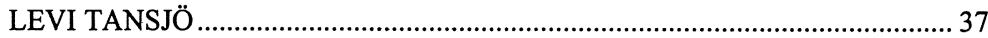

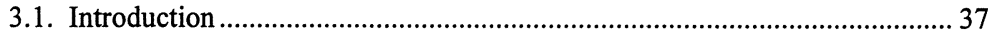

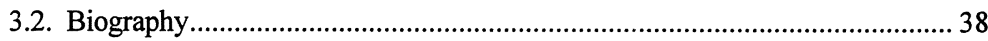

3.3. Mosander's Chemical Research ................................................................. 39

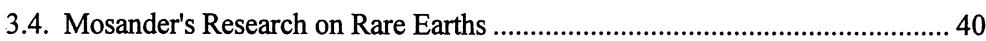




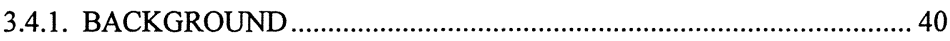

3.4.2. "SOMETHING ON CERIUM ........................................................... 41

3.4.3. THE DISCOVERY OF LANTHANUM........................................... 42

3.4.4. THE DISCOVERY OF DIDYMIUM ............................................... 45

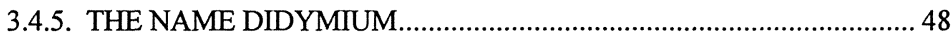

3.4.6. THE DISCOVERY OF TERBIUM AND ERBIUM ............................ 49

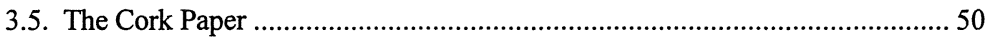

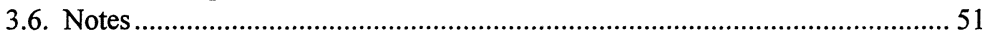

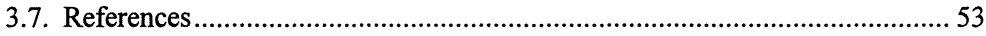

Chapter 4. THE 50 YEARS FOLLOWING MOSANDER .................................... 55

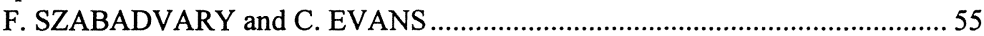

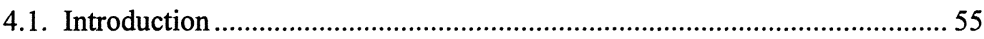

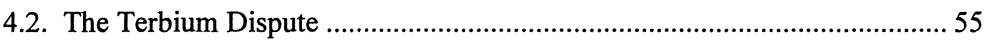

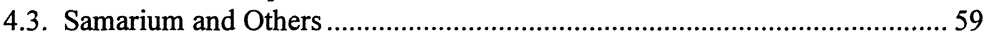

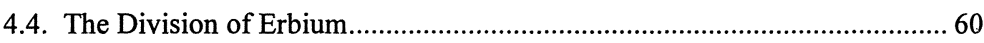

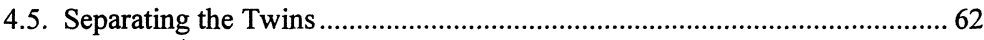

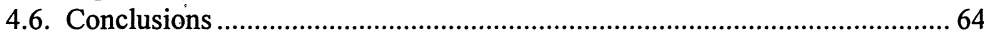

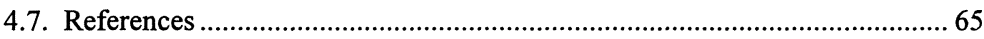

Chapter 5. ELEMENTS NO. 70, 71 AND 72: DISCOVERIES AND

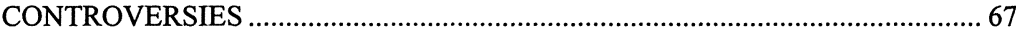

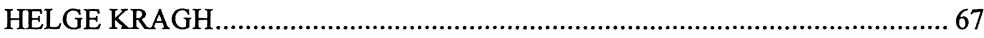

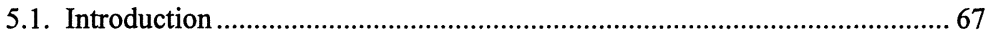

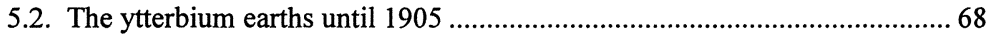

5.3. Auer von Welsbach: aldebaranium and cassiopeium ................................ 71

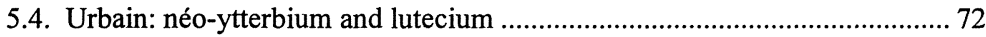

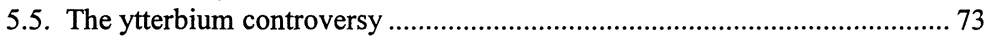

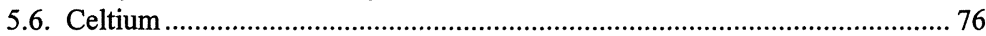

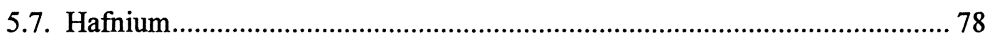

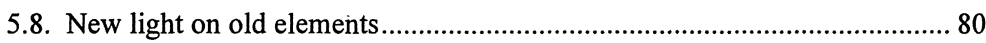

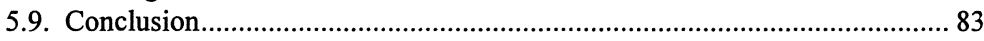

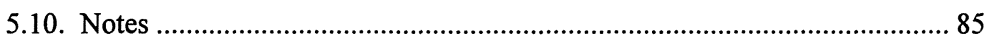

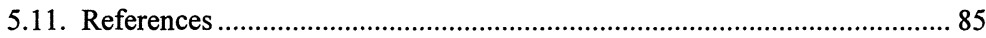

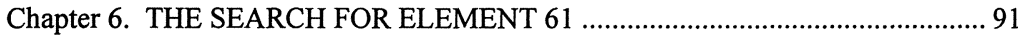

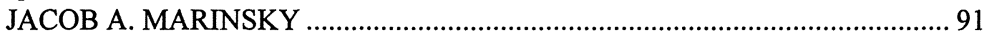

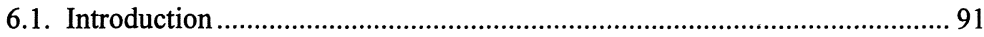

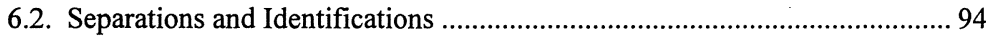

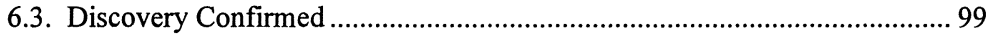

6.4. Announcing, Claiming and Naming Element 61 ................................... 102

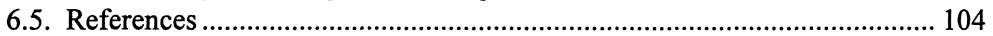


Chapter 7. CARL AUER VON WELSBACH A PIONEER IN THE INDUSTRIAL

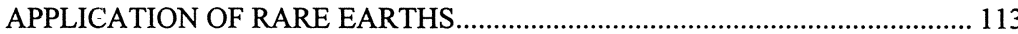

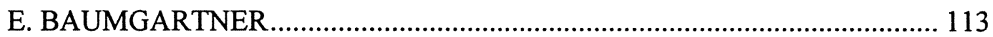

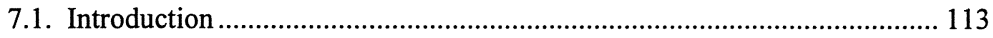

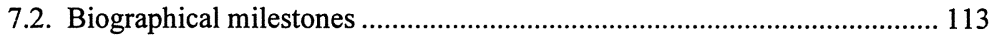

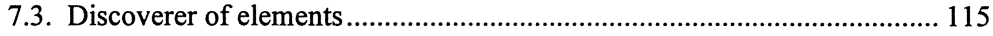

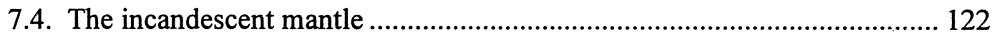

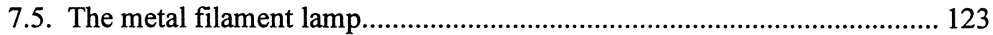

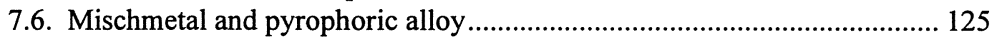

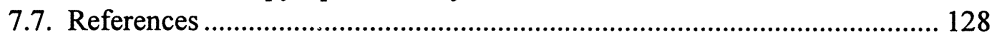

Chapter 8. THE HISTORY OF CHINA'S RARE EARTH INDUSTRY ............... 131

WANG MINGGIN and DOU XUEHONG .................................................... 131

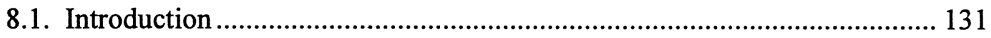

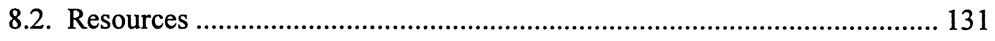

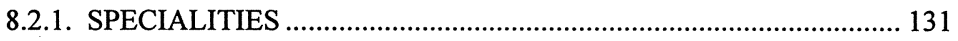

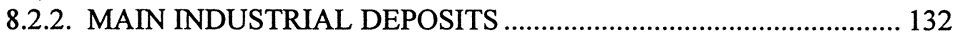

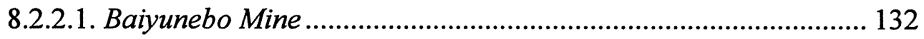

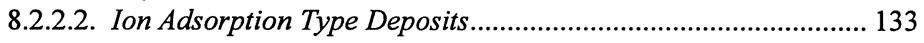

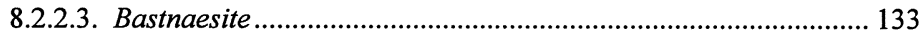

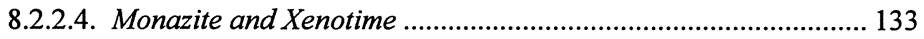

8.2.2.5. Rare Earth containing Collophanite ............................................ 134

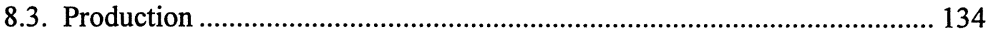

8.3.1. RAW MATERIAL AND PROCESSING TECHNOLOGY............... 134

8.3.1.1. Extraction of Rare Earths from Baiyunebo Ore ......................... 135

8.3.1.1.1. Blast furnace smelting--slag rich in rare earths--rare earth master alloy..................................................................................... 135

8.3.1.1.2. Ore-dressing --- rare earth concentrate -- rare earth product 135

8.3.1.2. Extraction of Rare Earths from Ion Adsorption Type Rare Earth

Minerals .......................................................................................... 137

8.3.2. SEPARATION AND PURIFICATION OF INDIVIDUAL RARE

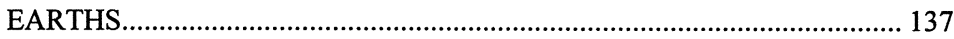

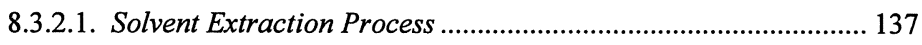

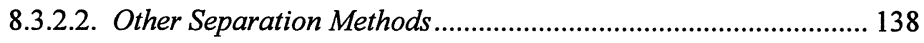

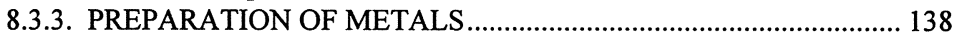

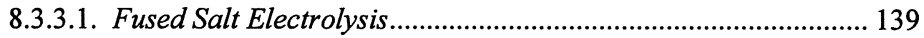

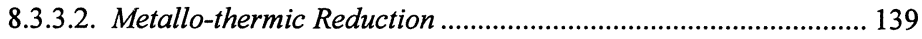

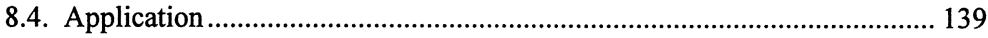

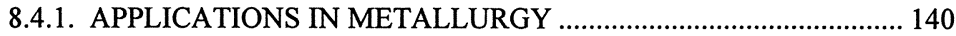

8.4.2. APPLICATIONS IN THE PETRO-CHEMICAL INDUSTRY .......... 143

8.4.3. APPLICATIONS IN GLASS AND CERAMICS ............................... 144

8.4.4. APPLICATIONS IN HIGH-TECHNOLOGY FIELDS ..................... 145

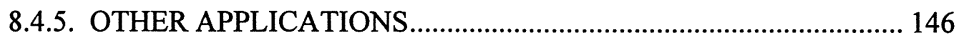


Chapter 9. RARE EARTH ELEMENTS IN THE GEOLOGICAL SCIENCES ... 149

EDWARD G. LIDIAK and WAYNE T. JOLLY .......................................... 149

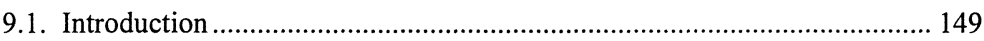

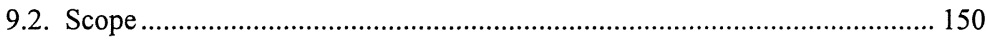

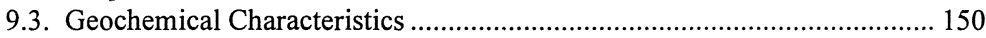

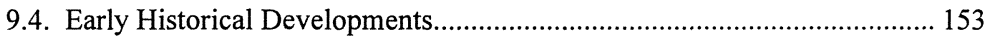

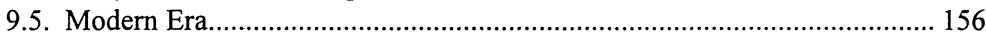

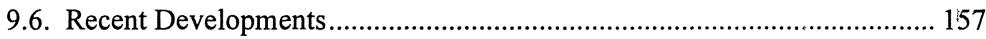

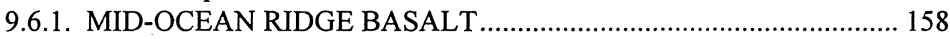

9.6.2. OCEAN ISLAND BASALT …..................................................... 158

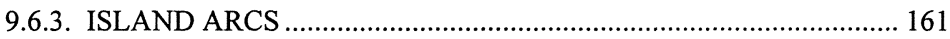

9.6.4. CONTINENTAL FLOOD BASALTS ............................................... 164

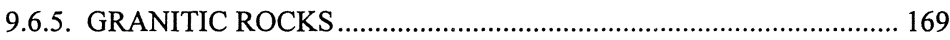

9.6.6. SOLUBILITY OF RARE EARTH ELEMENTS ............................. 172

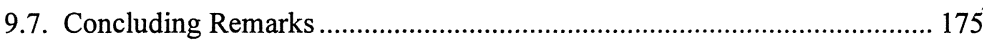

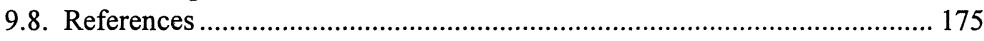

USE OF LANTHANUM AS A TOOL TO DELINEATE CALCIUM

MOBILIZATION PATTERNS IN SMOOTH MUSCLE..................................... 189

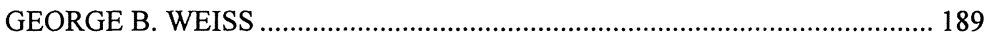

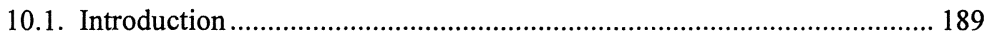

10.2. The Research Problem and the Idea to Use Lanthanum......................... 189

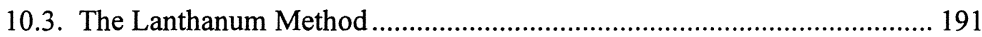

10.4. Validation and Use of the Lanthanum Method ..................................... 191

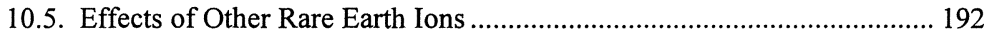

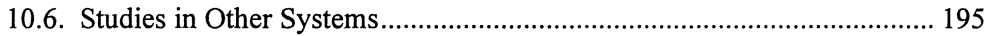

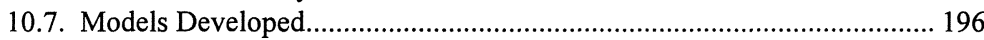

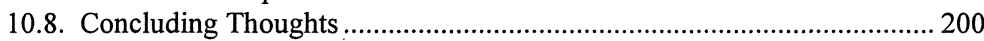

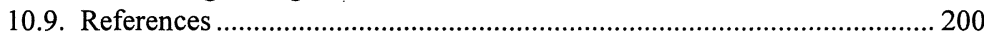

Chapter 11. MEDICAL USES OF THE RARE EARTHS...................................... 205

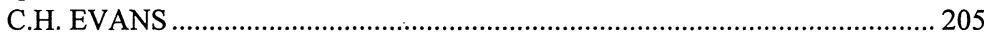

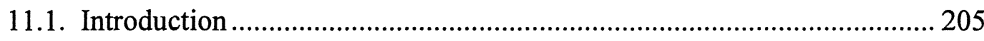

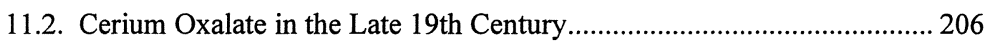

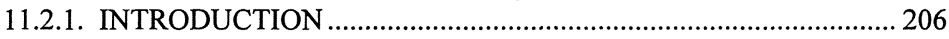

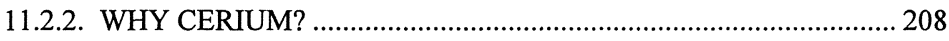

11.2.3. PROFESSIONAL RESPONSES TO THE USE OF CERIUM ........ 209

11.2.4. CERIUM'S FALL FROM FAVOUR........................................... 211

11.2.5. CERIUM OXALATE FOR THE RELIEF OF COUGHING ........... 212

11.3. Rare Earths As Anti-Microbial Agents ................................................. 213

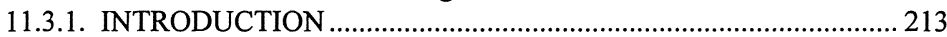

11.3.2. EARLY PRE-CLINICAL EXPERIENCES - CONTRIBUTIONS BY

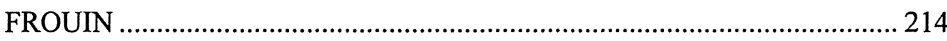


11.3.3. USE OF RARE EARTHS IN TUBERCULOSIS ..............................216

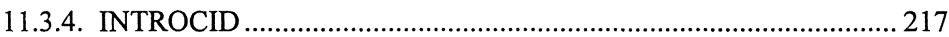

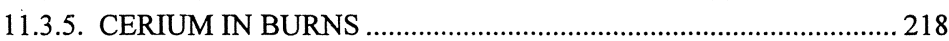

11.4. Lanthanides as Anti-coagulant and Anti-inflammatory Agents ............... 219

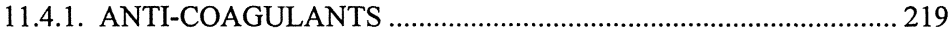

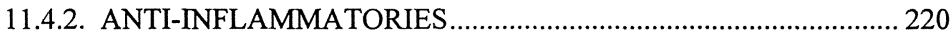

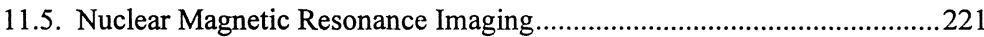

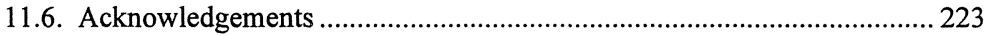

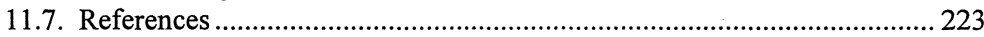

INDEX

229 


\section{Preface}

At the beginning of the "Biochemistry of the Lanthanides" (Plenum, NY, 1990), I made some remarks concerning the history of the rare earth elements and commented that there was "enough material here for an historian of science to write an instructive book on the identification of the lanthanides in its own right". Little did I think when writing these words that just a few years later I would be editing such a volume which, in recognition of the growing industrial, biological and medical importance of these elements, has been extended to include a second section, devoted to their application.

Interest in the history of these elements has been increasing in recent years, a trend accelerated by the bicentenary, in 1987, of the discovery of the first rare earth mineral. Although there exist scattered articles and book chapters pertaining to the history of the rare earths, there is only one other serious volume entirely devoted to historical matters concerning these elements: "Two hundred year impact of rare earths on science" edited by K.A. Gschneidner and L.R. Eyring (Elsevier, Amsterdam, 1988). This book, most chapters of which are highly technical and scientific in nature, contrasts with the present volume which concentrates more on matters of historiography and contextual interpretation. Taken together, they constitute comprehensive package both from the point of view of history and science.

All agree that the discovery of the rare earth elements began in 1787 when Carl Axel Arrhenius, a Swedish army officer, happened upon a new mineral which he named ytterbite after the nearby village of Ytterby. From this mineral the Finnish chemist Johan Gadolin isolated ytterbia $\left(\mathrm{Y}_{2} \mathrm{O}_{3}\right)$ in 1794 , thus fuelling an era of discovery that engaged many of the greatest chemists of the age. The Scandinavian origins of the rare earths are nicely reflected in the first three chapters of this volume, whose authors come from Finland and Sweden. Their contributions provide original insights into the work of Gadolin, Hisinger, Berzelius and Mosander, among others, which led to the identification of the first five rare earth elements.

The subsequent chapter summarizes the events of approximately 1850-1900 during which time technologic al and conceptual advances facilitated the discovery of all but two of the remaining rare earth elements. However, the chain of events set in motion by the discovery and chemical analysis of ytterbite, later re-named gadolinite, did not end until Marinsky unequivocally identified the final rare earth element promethium $(\mathrm{Pm})$ in 1947. It is a particular privilege to have in this book a valuable chapter by Professor Marinsky telling in his own words how this discovery came about.

Part I of this book provides much novel scholarship on the discovery of the rare earth elements. It is clear from these chapters that the isolation of these elements not only has a fascinating internal history, but also contains many episodes of broad significance to the wider history of chemistry and, indeed, to the history of science as a whole. The importance of technical innovation and theoretical advance to the process of chemical discovery are, for example, resoundingly exemplified by rare earth history. Light is 
shed upon the factors which determined the chemist's choice of problems and the robust empericism used in many cases to solve them. And, as exemplified in Dr. Helge Kragh's masterful chapter, these elements provide wonderful case studies for the analysis of priority disputes in scientific discovery.

Rare earth elements provided important challenges for Mendeleev's periodic table, which he revised on many occasions to accommodate these troublesome individuals. Yet this interplay proved profitable and helped to validate Mendeleev's system, which predicted the existence of "eka-boron" with properties corresponding to those of scandium. Moreover, the discovery of Pm heralded the first occasion on which an element which did not exist in nature was predicted, generated and discovered.

Part II of this book is devoted to the history of applying rare earths for practical purposes. Industrial application of the rare earths is inextricably linked to the Austrian chemist Carl Auer von Welsbach. It is difficult to overstate the importance of this individual to the commercial application of the rare earths, yet there is little biographical information to be found in the English language. The chapter by Dr. Edwin Baumgartner, who worked until recently at the Treibacher Chemical Works founded by Auer, is thus of particular value. According to this chapter, the origin of the rare earth industry can be traced to November 4, 1891, when Auer's gas mantle was used to illuminate a Viennese café. Baumgartner's analysis of Auer's life and work illustrates nicely how the search for practical utility, the demands of commerce and the process of scientific discovery can sometimes synergise.

China has the world's largest reserves of rare earth ores and is at the forefront of attempts to diversify and extend the industrial use of these elements. These efforts are spearheaded by scientists at the Baotou Research Institute in Inner Mongolia. A detailed chapter by two members of this institute describes the short history of this work and the present huge efforts to realise the full commercial potential of these elements.

Not all applications of the rare earths have economic ends. Improvements in methods for determining rare earth elements in geological samples, coupled to the advent of plate tectonic theory, has led to an explosion in the use of these elements in geochemistry. As comprehensively described by Drs. Edward Lidiak and Wayne Jolly, this continues to be a fruitful and ever growing area of application for the rare earth elements.

The last two chapters are biological in nature. Since the 1960s, it has become increasingly appreciated that trivalent lanthanide ions make excellent isomorphic replacements for calcium ions in biology and biochemistry. Being more informative than calcium, the lanthanides have been widely used to probe calcium sites in biology. A major application has been to study calcium binding sites on the surfaces of cells, particularly those which undergo stimulus-coupled responses. One of the pioneers of this field, Dr. Arthur Weiss, describes how these developments came about. Finally, 
xiii

there is a chapter analysing some of the various medical uses to which rare earth elements have been put.

In editing these chapters I have been at pains to make as few changes as was reasonably possible to the authors' original texts. This has inevitably led to a variety of styles of exposition, ranging from focussed, personal, first hand accounts to detached broad analyses. Nevertheless I believe that a book such as this, covering a wide range of topics dating from over 200 years ago to the near present, gains from this practice. Allowing individual authors free reign has also led to inevitable overlap between chapters but, again, I feel this is to the good. It permits each chapter to read separately and to be understood without reference to other chapters, while at the same time reinforcing the essential links that exist between the various facets of rare earth history.

By forming part of Kluwer's series of historical studies on "Chemistry and Chemists", I hope that this volume will make its information accessible to the wider audience and lead to greater interest in the rare earth elements and their history: 


\section{Acknowledgements}

The origins of this book lie with an invitation from Drs. Janjaap Blom who was, at that time, the Acquisition Editor for Kluwer Academic Press. He had read a short article entitled "The Discovery of the Rare Earth Elements", which I had written for Chemistry in Britain, and suggested that I might be interested in editing a book on the subject. With the completion of this volume, I am eager to express my gratitude to Drs. Blom for suggesting this project and encouraging me to undertake it. (I must admit there were times during the project's gestation when I wasn't quite so grateful).

There are relatively few scholars working in the suject area covered by this book. It was therefore important that those individuals whom I invited to contribute chapters would actually agree to do so. I would like to thank all the authors for their contributions and particularly for providing so much previously unpublished new scholarship as opposed to rehashes of existing information. Without their carefully written chapters this book would not, of course, exist. In this context, I thank Professor R.J.P. Williams of Oxford University for suggesting that I include a chapter on geochemistry, and Dr. Barry Kilbourne of Molycorp Inc. for putting me in touch with Dr. Edwin Baumgartner, then of Treibacher Schleifmittel, concerning the biography of Auer von Welsbach.

As usual, I am indebted to family, friends and colleagues for putting up with me while I engaged in yet another time-consuming distraction. Much of the chaos I generate in the pursuit of such enterprizes ends up on the desk of my secretary, Mrs. Lou Duerring. It goes almost without saying that without her intervention this book would still be unfinished. I am particularly grateful to Lou for rising to the occasion when, at the eleventh hour, it was decided to revise the book into a camera-ready format in order to speed up publication. Thanks Lou, for becoming an instant expert in desk-top publishing! 


\section{Introduction}

I am willing to venture the opinion that the history of the rare earths is more fascinating and illuminates more areas of chemical progress, than the history of any other group of elements. Such a position resonates with the assessment of the mineralogist Flint who is reported to have claimed that ytterbite was maybe the most significant single mineral in the history of inorganic chemistry. Perusal of the first part of this book will provide much support for such statements.

Asccording to IUPAC nomenclature, the rare earth series comprises elements $2 \mathrm{i}(\mathrm{Sc})$, $39(\mathrm{Y})$ and $57(\mathrm{La})$ to $71(\mathrm{Lu})$. The first of these to be discovered was yttrium. It begal in the summer of 1787 when the Swedish army office, Carl Arrhenius found a heavy, black mineral which he named ytterbite after the adjacent village of ytterby. In 1794 the Finnish chemist Gadolin isolated from ytterbite a new earth, which we now know tr. be yttria - $\mathrm{Y}_{2} \mathrm{O}_{3}$. Although yttrium was not obtained in pure, elemental form, Gadolin's 1794 isolation is taken to represent the discovery of the first rare earth. Production of the first of this series in elemental form had to await Mosander's reduction of ceria to cerium in 1826.

Gadolin's isolation of yttria represented the first of a number of rare earths that were extracted from ytterbite, later renamed gadolinite by Ekeberg. As indicated in figure 1, and as explained in detail in the first part of this book, chemical analysis of gadolinite was responsible for the discovery of 9 members of the rare earth series. These are sometimes referred to as the "yttric" group. Discovery of all but one of the remaining $\varepsilon$ elements can be traced directly or indirectly to the mineral cerite. These elements are sometimes referred to as the "ceric" group.

Cerite, originally called tungsten, served as the starting material for the isolation in 1803 of ceria $\left(\mathrm{Ce}_{2} \mathrm{O}_{3}\right)$ by Berzelius and Hisinger in Sweden and, independently, by Klaproth in France. In chapter 2, Professor Jan Trofast provides details of the ensuing priority dispute - the first of several along the pathway of rare earth discovery.

As shown in figure 1, cerite brought forth not only cerium, but also lanthanum and didymium; the latter was shown to be a mixture of praseodymium and neodymium. Progress in this direction was aided by the discovery of more abundant rare earth minerals, such as samarskite. Although identified in the USA in 1878, it was named after the Russian mining engineer Samarsky who had earlier found this mineral in the Urals. Rare earth chemists were also aided by Auer von Welsbach's importation of large amounts of monazite sand as a commercial source of rare earths (Chapter 7).

In reading accounts of the discoveries of the rare earth elements, one is struck by the ways in which technology and, later, theory both aided and, in some cases, hindered progress. Up until the advent of ion exchange chromatography in the 20th century, chemists were forced to use inefficient and laborious techniques such as fractional precipitation and crystallisation, to separate rare earths. Because the chemical 
properties of the various members of this series are so similar, their separation and purification was an enormous undertaking which would have difficulty attracting grant support today. Tens of thousands of repetitive fractionations were required to produce tiny amounts of purified material.

Problems of purification were compounded by the lack of good methods for identifying elements and assessing their purity, as well as complete ignorance of the number of different rare earths that actually existed. Spectral analysis, introduced by Bunsen and Kirchhoff in 1859, and the development and refinement of Mendeleev's periodic system provided partial answers to these problems. Their impact is clear. In the 60 years or so prior to the introduction of these two advances, only 6 rare earths had been identified and one of these, didymium, did not exist. During the subsequent 50 years, the list of rare earth elements jumped to 15 , only lutetium and promethium being absent.

The interplay between Mendeleev's periodic system and the rare earth elements is an interesting one, worthy of deeper analysis by future scholars. For instance,

Mendeleev's system predicted the existence of scandium and accurately foretold several of its properties. In this sense, the rare earths facilitated acceptance of Mendeleev's proposed periodic system. Nevertheless, the other rare earth elements severely challenged his system, because he didn't know where to place them. Many modifications were made simply to accommodate these elements. Such difficulties continues to dog Mendeleev until his death. Meanwhile, spectroscopic analysis was proving to be as much a hindrance as a help. Because of the spectral complexity of the rare earths, the difficulty of preparing them to high purity and the unreliability of spectroscopy in inexperienced hands, rare earth elements were being discovered in ridiculous numbers; over 70 in just a few years. Clearly something was wrong, but without knowing how many rare earth elements actually existed, it was hard to know how to resolve the issue.

Relief came in the form of Moseley's finding, in 1913, that the atomic number of an element could be determined from its X-ray spectrum. Calculations based upon these premises quickly revealed that all possible rare earth elements had already been discovered, except one - element 61 . Here is a good example of theory coming to the aid of practice. Thanks to Moseley's theory, effort need not be wasted looking for nonexistent elements; instead, resources could be re-directed towards the discovery of the final missing member. This was finally achieved in 1947 (Table 1).

Of interest to historians of science is the resistance to Moseley's ideas from certain chemists. As Dr. Kragh points out in chapter 5, this is an illustrative case of a "boundry conflict" between disciplines, complicated by the clash of cultures occurring between the older, practical, experimentalists and the new theoreticians. This chapter also provides an illuminating analysis of the priority dispute between Auer von Welsbach and Urbain over the discovery of element 71 . Also pointed out is the possibility that both of these chemical giants may have been beaten to the punch by Charles James at 
xix

the University of New Hampshire. For some reason, perhaps timidity in the face of such a viscious priority battle by two such noted individuals, James did not pursue his claim.

Discovery of the final rare earth was impeded by the fact that it is an unstable, radioactive element that exists naturally on earth in only the minutest of quantities. There were several false starts in the search for element 61 , including some strange behaviour on the part of two Florentine scientists who claimed to have discovered the element in 1924 but, for reasons that are completely obscure, to have locked the manuscript away in the Academia dei Lincei. This odd circumstance was only revealed in 1926 when scientists at the University of Illinois claimed to have isolated the same element. In the event, all such claims were groundless. Element 61 was unequivocally isolated for the first time by Marinsky's group in 1947; Professor Marinsky tells how this came about in chapter 6. Particularly impressive is the manner in which the senior scientist associated with the project, Professor Coryell, removed his own name from the paper announcing the discovery, so as not to detract from the accomplishments of the other, more junior investigators.

The first practical application of a rare earth seems to have been in the unlikely role as a medicine. An 1854 paper by Professor Simpson of Edinburgh, Scotland, extolled the benefits of using cerium nitrate to treat the reflex vomiting of pregnancy. He later switched to recommending cerium oxalate which, in a short space of time, became highly prescribed for the treatment of all types of vomiting, including sea-sickness, as well as for coughs and even various nervous disorders such as epilepsy and chorea. The popularity of cerium oxalate waned almost as quickly as it had arisen, and it is no longer used for this purpose Since that time, however, various rare earth salts have been used as antimicrobial agents for the treatment of infectious diseases, as anticoagulants, and as antiinflammatory agents. Today, cerium nitrate is used to treat burns and GdDTPA is used as a contrast enhancing agent in magnetic resonance imaging.

By a route that is completely unrelated to medical use, rare earths have become widely used as experimental tools in cell biology and biochemistry. Trivalent cations of the rare earth metals serve as informative, isomorphous replacements for calcium ions which, although ubiquitous and extremely important in biology, are spectroscopically dead. One aspect of this application, as a way to probe calcium-binding to the surface of muscle cells, is described in chapter 10 by one of the pioneers of this field.

Another important scientific application of the rare earth elements is in the area of geochemistry (chapter 9). Here again we see how such a use requires the combination of an underlying theory, in this case plate tectonics, with the appropriate technological sophistication, in this case the ability to measure tiny concentrations of rare earth elements to high accuracy.

Industrial application of the rare earths began on November 4, 1891 outside the Opern café in Vienna (Chapter 7). Carl Auer von Welsbach had invented an incandescent gas 
mantle comprising a thin fabric inpregnated with thorium oxide and cerium oxide. After the demonstration in Vienna, this form of illumination rapidly gained widespread use and the city of Bombay used it for public lighting. As well as initiating the industrial use of the rare earths, Auer von Welsbach isolated praseodymium and neodymium from didymium and discovered lutetium, which he called cassiopeium . The priority dispute between Urbain and Auer von Welsbach concerning element 71 had already been mentioned.

Auer von Welsbach also invented a lighter flint based upon alloy of iron and cerium, which became a huge commercial success. Because of these successes, the chemical works founded by Auer in Treibach, Austria is still in operation. Auer required an abundant source of rare earth minerals, which he satisfied by realising the properties of an ore called monazite which occurred in the New World and was, until that time, used as ballast by sailing ships.

China has the world's largest reserves of rare earth ores and is understandably eager to exploit them commercially. As described in chapter 8, the history of rare earth applications in China is relatively short. Their production in China did not begin until the 1950s and most of the major deposits were not identified until the 1960s. Research programmes to improve extraction procedures and processing have been in place since this time. New uses are also being actively sought not only in traditional areas of technology, but also in such areas as agriculture, where the Chinese claim that the use of fertilizers containing the rare earths improves growth and increases yields. 


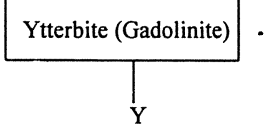

1794
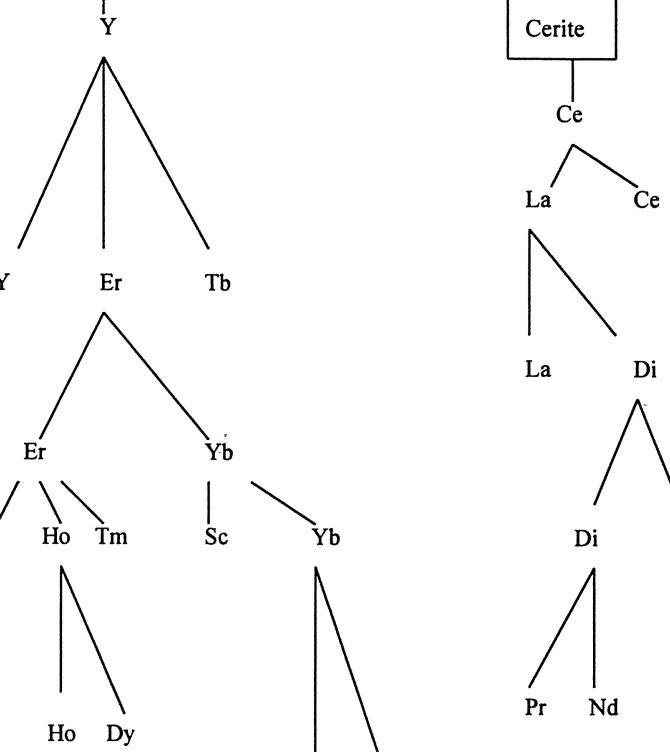

1907
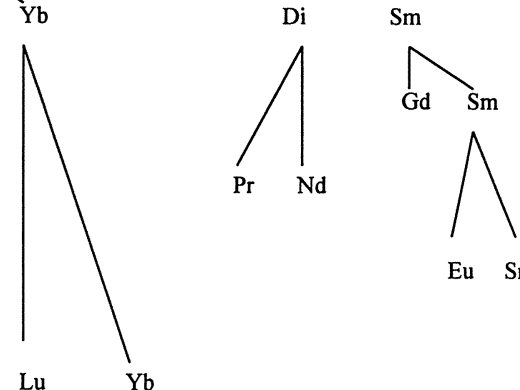

Figure 1 Chronology and dendrology of the isolation of rare earths.

As this diagram illustrates, the discovery of each of the stable rare earth elements can be traced to a "yttric" or "ceric" origin. Progress was delayed by the rarity of ytterbite (gadolinite) and cerite, a deficiency that was remedied by the discovery of Samarskite and, later, Monazite which are abundant rare earth ores.

The rare earths were not initially isolated as pure metals but, rather, as impure preparations of their salts. Mosander purified the first rare earth compound, lanthana $\left(\mathrm{La}_{2} \mathrm{O}_{3}\right)$ and later prepared a rare earth $(\mathrm{Ce})$ in metallic form for the first time.

With the exception of didymium, when a previously pure rare earth was shown to contain an additional earth, or earths, one of the new elements retained the original name of the mother element, while the other daughter element was provided with a new name. 
xxii

Table 1 Discovery and etymology of the rare earths

\begin{tabular}{|c|c|c|c|c|}
\hline Rare Earth & $\begin{array}{l}\text { Year of } \\
\text { Discovery }\end{array}$ & Discoverer & $\begin{array}{l}\text { Origin of } \\
\text { Name }\end{array}$ & Reference \\
\hline Yttrium (Y) & 1794 & Gadolin & $\begin{array}{l}\text { Ytterby, a village } \\
\text { near Stockholm }\end{array}$ & Chapter 1 \\
\hline Cerium (Ce) & 1803 & $\begin{array}{l}\text { (i) Berzelius \& } \\
\text { Hisinger } \\
\text { (ii) Klaproth }\end{array}$ & $\begin{array}{l}\text { Ceres, an asteroid } \\
\text { discovered in } 1801\end{array}$ & Chapter 2 \\
\hline Lanthanum (La) & 1839 & Mosander & $\begin{array}{l}\text { To lie hidden } \\
\text { (Greek) }\end{array}$ & Chapter 3 \\
\hline Erbium (Er) & 1843 & Mosander & Ytterby & Chapters $3 \& 4$ \\
\hline Terbium (Tb) & 1843 & Mosander & Ytterby & Chapters $3 \& 4$ \\
\hline Ytterbium (Yb) & 1878 & Marignac & Ytterby & Chapters $4 \& 5$ \\
\hline Holmium (Ho) & 1879 & Cleve & $\begin{array}{l}\text { Stockholm } \\
\text { (Latin) }\end{array}$ & Chapter 4 \\
\hline Thulium (Tm) & 1879 & Cleve & $\begin{array}{l}\text { Northernmost } \\
\text { region of the } \\
\text { inhabitable world } \\
\text { (Latin) }\end{array}$ & Chapter 4 \\
\hline Scandium (Sc) & 1879 & Nilson & Scandanavia (Latin) & Chapter 4 \\
\hline Samarium (Sm) & 1879 & $\begin{array}{l}\text { Lecoq } \\
\text { DeBoisbaudran }\end{array}$ & $\begin{array}{l}\text { Samarskite, an ore } \\
\text { named after the Russi } \\
\text { army officer Samarsk }\end{array}$ & $\begin{array}{l}\text { Chapter } 4 \\
\text { ian } \\
y\end{array}$ \\
\hline Gadolinium (Gd) & 1880 & Marignac & Johan Gadolin & Chapter 4 \\
\hline Praseodymium (Pr) & 1885 & Auer & Green twin (Greek) & Chapters 4 \& 7 \\
\hline Neodymium (Nd) & 1885 & Auer & New twin (Greek) & Chapters 4 \& 7 \\
\hline Dysprosium (Dy) & 1886 & $\begin{array}{l}\text { Lecoq } \\
\text { DeBoisbaudran }\end{array}$ & $\begin{array}{l}\text { Hard to get at } \\
\text { (Greek) }\end{array}$ & Chapter 4 \\
\hline Europium (Eu) & 1901 & Demarçay & Europe & Chapter 4 \\
\hline Lutetium (Lu) & 1907 & $\begin{array}{l}\text { (i) Auer } \\
\text { (ii) Urbain }\end{array}$ & $\begin{array}{l}\text { Paris } \\
\text { (Latin) }\end{array}$ & Chapters $5 \& 7$ \\
\hline Promethium (Pm) & 1947 & $\begin{array}{l}\text { Marinsky } \\
\text { Glendenin } \\
\text { Coryell }\end{array}$ & $\begin{array}{l}\text { Prometheus, } \\
\text { Greek God }\end{array}$ & Chapter 6 \\
\hline
\end{tabular}

